\title{
Short communication: Insertion of an intravaginal progesterone device at the time of gonadotropin-releasing hormone (GnRH) injection affects neither GnRH-induced release of luteinizing hormone nor development of dominant follicle in early diestrus of lactating dairy cows
}

\author{
L. G. D. Mendonça, ${ }^{*} \ddagger^{1}$ M. Amstalden, $\dagger$ and R. C. Chebel $\ddagger$ \\ *Department of Animal Sciences and Industry, Kansas State University, Manhattan 66506 \\ †Department of Animal Science, Texas A\&M University, College Station 77843 \\ łDepartment of Veterinary Population Medicine, University of Minnesota, Saint Paul 55108
}

\begin{abstract}
Our objectives were to evaluate the acute effects of a controlled internal drug release (CIDR) insert containing $1.38 \mathrm{~g}$ of progesterone $(\mathrm{P} 4)$ on the release of LH, follicular growth, and circulating concentrations of P4 in cows treated with GnRH at the time of CIDR insertion. Nonpregnant, lactating dairy cows ( $\mathrm{n}=$ 27) were blocked by parity, predicted 305-d matureequivalent milk production, and body condition score and randomly assigned to 1 of 3 treatments: (1) CIDR insertion concurrent with an injection of $200 \mu \mathrm{g}$ of GnRH ( $\mathrm{n}=10 ; 2 \mathrm{GP} 4)$; (2) CIDR insertion concurrent with an injection of $100 \mu \mathrm{g}$ of $\mathrm{GnRH}(\mathrm{n}=10 ; 1 \mathrm{GP} 4)$; and (3) injection of $100 \mu \mathrm{g}$ of $\mathrm{GnRH}(\mathrm{n}=7$; CON). Prior to onset of treatments, cows were submitted to a presynchronization protocol that consisted of a CIDR insert containing $1.38 \mathrm{~g}$ of $\mathrm{P} 4$ from $\mathrm{d}-7$ to $-2,25 \mathrm{mg}$ of $\mathrm{PGF}_{2 \alpha}$ on $\mathrm{d}-2$ and -1 , and $100 \mu \mathrm{g}$ of $\mathrm{GnRH}$ on $\mathrm{d}$ 0 . Experimental treatments were applied on $\mathrm{d} 6$, the early luteal phase of the estrous cycle. Concentrations of $\mathrm{P} 4$ in plasma were determined on $\mathrm{d}-2$ and 0 and at $0,15,30,60,120,240,345,600$, and 1,200 min relative to treatment on $\mathrm{d} 6$. Concentrations of $\mathrm{LH}$ were determined in plasma samples obtained at $0,15,30,60$, 120,240 , and 345 min relative to treatment on d 6 . Ultrasonography examinations of ovarian structures were performed on $\mathrm{d}-2,0,2$, and at 0,600 , and 1,200 min relative to treatment on $\mathrm{d} 6$. Mean concentrations of $\mathrm{P} 4$ in the CON group $(1.91 \pm 0.28 \mathrm{ng} / \mathrm{mL})$ were lower than in 2GP4 $(3.40 \pm 0.26 \mathrm{ng} / \mathrm{mL})$ and $1 \mathrm{GP} 4(3.31$ $\pm 0.24 \mathrm{ng} / \mathrm{mL}$ ) groups, but concentrations in $2 \mathrm{GP} 4$ and 1GP4 were similar. Mean concentration of LH in response to the $\mathrm{GnRH}$ injection on d 6 was greatest
\end{abstract}

Received November 24, 2014

Accepted February 28, 2015.

${ }^{1}$ Corresponding author: mendonca@k-state.edu in $2 \mathrm{GP} 4$ cows $(3.08 \pm 0.21 \mathrm{ng} / \mathrm{mL})$ and did not differ between 1GP4 $(2.23 \pm 0.21 \mathrm{ng} / \mathrm{mL})$ and CON (2.14 $\pm 0.25 \mathrm{ng} / \mathrm{mL}$ ) cows. The diameter of the dominant follicle on d 6 was similar among treatments $(2 \mathrm{GP} 4=$ $15.34 \pm 0.50 ; 1 \mathrm{GP} 4=15.31 \pm 0.50 ; \mathrm{CON}=14.77 \pm$ $0.62 \mathrm{~mm})$. In conclusion, CIDR insertion concurrent with a 100- or 200- $\mu \mathrm{g}$ dose of GnRH neither altered GnRH-induced LH release nor had an acute effect on dominant follicle growth.

Key words: dairy cow, controlled internal drug release insert, exogenous progesterone, luteinizing hormone

\section{Short Communication}

Suboptimal estrus detection in confinement-based dairy systems has resulted in a marked increase in the utilization of timed AI (TAI) synchronization programs. As reported in NAHMS (2007), 58.2\% of dairy operations use TAI synchronization programs for reproductive management. Timed AI protocols are based on the ultimate goal of inducing synchronized ovulation; therefore, cows can be inseminated in a timely manner, with the expectation of increasing AI submission rates and pregnancy rates. Synchronized recruitment of a new follicular wave following initiation of GnRH-based protocols is necessary for successful ovulation at TAI. As demonstrated by Vasconcelos et al. (1999), synchronization rate of the Ovsynch protocol was greater for cows that ovulated in response to the first GnRH injection of the protocol compared with cows that did not ovulate. Furthermore, the lack of ovulatory response to the first GnRH injection of GnRH-based protocols results in prolonged dominance of the ovulatory follicle, reduced embryo quality (Cerri et al., 2009), and reduced pregnancy per AI (Chebel et al., 2006).

Adding a controlled internal drug release (CIDR) insert containing progesterone (P4) to ovulation synchronization protocols is a common practice in dairy operations (NAHMS, 2007). Chebel et al. (2010) pro- 
posed that the inclusion of a CIDR insert containing $1.38 \mathrm{~g}$ of $\mathrm{P} 4$ in ovulation synchronization protocols prevents premature ovulation in cows that exhibit luteolysis during TAI protocols, improved synchrony of estrus at the end of the protocol, and improved pregnancy per AI. Moreover, Lima et al. (2009) demonstrated that cows treated with a CIDR insert had reduced incidence of asynchronous estrus cycle following TAI, indicating improved synchronization of the estrous cycle.

Conversely, Galvão et al. (2004) and Stevenson et al. (2008) reported that the inclusion of a CIDR insert in ovulation synchronization protocols decreased the percentage of cows that ovulated in response to the first GnRH injection in GnRH-based TAI protocols. Decreased ovulation rate following the first GnRH injection affects successful induction of a new follicular wave and has a detrimental effect on synchrony of the estrous cycle, embryo quality, and pregnancy per AI (Vasconcelos et al., 1999; Chebel et al., 2006; Cerri et al., 2009). The effect of a CIDR treatment concomitant with a GnRH injection on ovulatory responses, however, remains controversial because other studies have demonstrated no difference in ovulatory responses in cows treated or not with a CIDR insert when given a GnRH injection (Lima et al., 2009; Chebel et al., 2013).

Some evidence suggests that P4 may decrease the estradiol-induced expression of GnRH receptors in the pituitary tissue of sheep (Rispoli and Nett, 2005), thus influencing pituitary responsiveness to GnRH. Kirkpatrick et al. (1998) demonstrated that removal of P4 implants of ovariectomized ewes supplemented with P4 and estradiol resulted in increased amounts of $\mathrm{GnRH}$ receptor mRNA in the pituitary glands. We anticipated that exogenous P4 would decrease the sensitivity of gonadotrophs to $\mathrm{GnRH}$ in cattle and hypothesized that the concurrent insertion of a CIDR and injection of GnRH would decrease the GnRH-induced release of $\mathrm{LH}$ and diminish growth of the dominant follicle. In addition, we tested whether an increased dose of GnRH at the time of CIDR insertion would increase LH release and restore dominant follicle growth.

Cows used in the present study were housed in a tiestall barn at the University of Minnesota's St. Paul dairy. Nonpregnant lactating dairy cows $(\mathrm{n}=40)$ were presynchronized with a CIDR insert (Eazi-Breed CIDR Cattle Insert; Pfizer Animal Health, Madison, $\mathrm{NJ})$ containing $1.38 \mathrm{~g}$ of $\mathrm{P} 4$ from $\mathrm{d}-7$ to -2 . On $\mathrm{d}$ -2 and -1 , cows were treated with $\mathrm{PGF}_{2 \alpha}(25 \mathrm{mg}$ of dinoprost tromethamine, $5 \mathrm{~mL}$ of Lutalyse sterile solution; Pfizer Animal Health). On d 0, cows received a GnRH injection $(100 \mu \mathrm{g}$ of gonadorelin diacetate tetrahydrate; $2 \mathrm{~mL}$ of Cystorelin; Merial Ltd., Iselin, NJ). The day of the GnRH injection was considered d 0 of the estrous cycle (Figure 1). Body condition score was assessed on a scale of 1 (severe under-conditioning) to 5 (severe over-conditioning) on estrous cycle d 0 as described by Ferguson et al. (1994). Cows had their ovaries examined by ultrasonography (Aloka SSD 550 ultrasound equipped with a linear $5-\mathrm{MHz}$ rectal probe; Aloka, Tokyo, Japan) on d $-2,0$, and 2 to evaluate luteal regression and ovulatory response to the $\mathrm{GnRH}$ injection, which were considered eligibility criteria for cows to continue in the study. Ovulation was characterized by the disappearance of follicles $\geq 10 \mathrm{~mm}$, and luteal regression was characterized by decreased size in luteal tissue $(>70 \%$ reduction in luteal volume within $48 \mathrm{~h}$ of $\mathrm{PGF}_{2 \alpha}$ treatment). Corpus luteum (CL) volume was calculated by the following formula (Kenyon et al., 2012):

$$
\begin{aligned}
& \Sigma\left(\left\{4 / 3 \times \pi \times\left[\left(\mathrm{d}_{\mathrm{a}} / 2+\mathrm{d}_{\mathrm{b}} / 2\right) / 2\right]^{3}\right\}\right. \\
- & \left.\left\{4 / 3 \times \pi \times\left[\left(\mathrm{c}_{\mathrm{a}} / 2+\mathrm{c}_{\mathrm{b}} / 2\right) / 2\right]^{3}\right\}\right),
\end{aligned}
$$

where $d_{a, b}$ and $c_{a, b}$ are orthogonal luteal and cavity dimensions, respectively, for the $n$th CL.

Thirteen cows were excluded from the study because they either did not have luteal regression or did not ovulate in response to the $\mathrm{GnRH}$ injection given on d 0 . Cows $(n=27)$ that met eligibility criteria were blocked by parity, predicted 305-d mature-equivalent milk yield, and BCS. Cows were then assigned randomly to 1 of 3 treatments: (1) control (CON), in which cows were treated with $100 \mu \mathrm{g}$ of $\mathrm{GnRH}$ on $\mathrm{d} 6$ ( $\mathrm{n}=$ 7 multiparous cows); (2) $100 \mu \mathrm{g}$ of GnRH concurrently with a CIDR insert (1GP4; $\mathrm{n}=10,8$ multiparous and 2 primiparous); and (3) $200 \mu \mathrm{g}$ of GnRH concurrently with a CIDR insert (2GP4; $\mathrm{n}=10 ; 8$ multiparous and 2 primiparous). Blood samples were collected from the coccygeal vein or artery using evacuated tubes containing $\mathrm{K}_{2}$ EDTA (Becton Dickinson Vacutainer Systems, Franklin Lakes, NJ) on d -2 and 0 and at $0,15,30,60$, $120,240,345,600$, and 1,200 min relative to treatment given on d 6. Samples were placed on ice until centrifugation at $1,200 \times g$ for $15 \mathrm{~min}$ at $4^{\circ} \mathrm{C}$. Plasma was separated and frozen at $-32^{\circ} \mathrm{C}$ for hormone analysis. Concentrations of $\mathrm{P} 4$ were determined in all samples using a solid-phase radioimmunoassay kit (Coat-a-Count, Siemens Medical Solutions Diagnostics, Los Angeles, CA). Intra- and interassay coefficients of variation were 5.99 and $5.95 \%$, respectively. Blood samples collected on d 6 from 0 to 345 min relative to treatment were used for determination of concentrations of LH using a double-antibody RIA as previously described by Rivera et al. (2011). Intra- and interassay coefficients of variation were 8.4 and $17.0 \%$, respectively. Ultrasonographic examinations of the ovaries were performed at 0,600 , and 1,200 min relative to treatment on d 6 to evalu- 

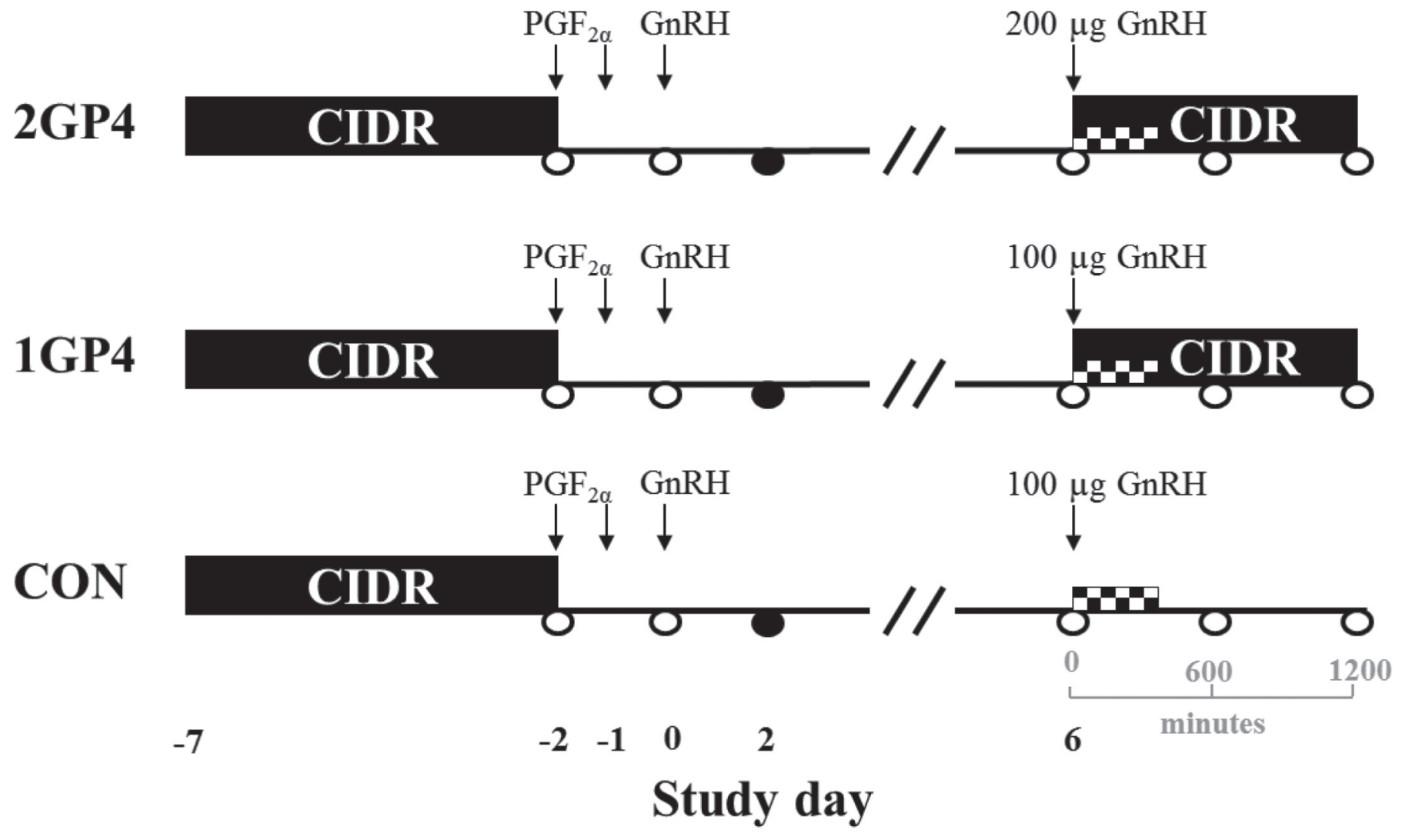

blood sample and ultrasonographic examination of the ovaries

ultrasonographic examination of the ovaries

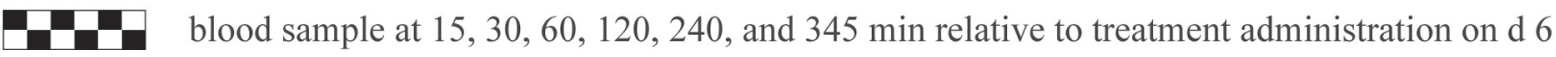

Figure 1. Study diagram of activities. All cows were presynchronized with a progesterone insert for 5 d, 2 injections of prostaglandin given 24 $\mathrm{h}$ apart starting at controlled internal drug release (CIDR) removal, and a GnRH injection $2 \mathrm{~d}$ after CIDR removal. Cows received the assigned treatment on d $6.2 \mathrm{GP} 4=200 \mu \mathrm{g}$ of $\mathrm{GnRH}$ concurrently with progesterone treatment; $1 \mathrm{GP} 4=100 \mu \mathrm{g}$ of GnRH concurrently with progesterone treatment: $\mathrm{CON}=100 \mu \mathrm{g}$ of $\mathrm{GnRH}$ treatment. CIDR = controlled internal drug release insert containing $1.38 \mathrm{~g}$ of progesterone (Eazi-Breed CIDR Cattle Insert; Pfizer Animal Health, Madison, NJ); $\mathrm{PGF}_{2 \alpha}=25 \mathrm{mg}$ of dinoprost tromethamine (5 mL of Lutalyse sterile solution; Pfizer Animal Health); GnRH = $100 \mu \mathrm{g}$ of gonadorelin diacetate tetrahydrate $(2 \mathrm{~mL}$ of Cystorelin; Merial Ltd., Iselin, NJ); open circle $=$ blood sample and ultrasonographic examination of the ovaries; filled circle $=$ ultrasonographic examination of the ovaries; checkerboard pattern $=$ blood sample at $15,30,60,120,240$, and 345 min relative to treatment administration on $\mathrm{d} 6$.

ate ovarian structures. Lastly, at 1,200 min, a follicular fluid sample from the dominant follicle was collected by transvaginal ultrasound-guided aspiration for hormone analysis (data not shown).

Dominant follicle diameter, CL volume, and hormone concentrations during presynchronization and at treatment administration on d 6 ( 0 min) were analyzed by ANOVA using the GLM procedure of SAS (ver. 9.2; SAS Institute Inc., Cary, NC). Dominant follicle diameter and hormone concentrations after treatment on d 6 were analyzed by ANOVA for repeated measures using the MIXED procedure of SAS. Dominant follicle diameter and hormone concentrations at the time of treatment $(0 \mathrm{~min})$ were used as covariates for the repeated measure analysis from 0 to 1,200 min relative to treatment. Models included treatment (CON, 1GP4, and 2GP4) and the interaction between treatments and time relative to treatment. In the current study, statistical significance was defined as $P<0.05$ and statistical tendencies as $0.05 \leq P \leq 0.15$.

Predicted 305-d mature-equivalent milk production $(9,835.7 \pm 352.0 \mathrm{~kg} ; P=0.66), \mathrm{BCS}(2.80 \pm 0.10 ; P=$ $0.55)$, and DIM $(172.8 \pm 14.8 ; P=0.66)$ did not differ among treatments. Concentrations of $\mathrm{P} 4$ before treat- 
Table 1. Progesterone concentrations on $\mathrm{d}-2,0$, and 6 , and corpus luteum volume on $\mathrm{d} 6$ according to treatments

\begin{tabular}{|c|c|c|c|c|}
\hline Item & \multicolumn{3}{|c|}{ Treatment $^{1}$} & $P$-value \\
\hline Progesterone concentration on $\mathrm{d}-2, \mathrm{ng} / \mathrm{mL}$ & $1.89 \pm 1.07$ & $2.91 \pm 0.90$ & $2.76 \pm 0.90$ & 0.75 \\
\hline Progesterone concentration on $\mathrm{d} 6, \mathrm{ng} / \mathrm{mL}$ & $1.37 \pm 0.38^{\mathrm{a}}$ & $1.18 \pm 0.32^{\mathrm{a}}$ & $2.44 \pm 0.32^{\mathrm{b}}$ & 0.02 \\
\hline Corpus luteum volume on $\mathrm{d} 6, \mathrm{~mm}^{3}$ & $5,167.8 \pm 1,020.1$ & $5,327.1 \pm 853.5$ & $5,057.3 \pm 853.5$ & 0.98 \\
\hline
\end{tabular}

${ }^{\mathrm{a}, \mathrm{b}}$ Within row, values with different superscripts differ $(P<0.05)$.

${ }^{1} \mathrm{CON}=$ cows were treated with $100 \mu \mathrm{g}$ of $\mathrm{GnRH}$ on d $6 ; 1 \mathrm{GP} 4=100 \mu \mathrm{g}$ of GnRH concurrently with a CIDR insert; $2 \mathrm{GP} 4=200 \mu \mathrm{g}$ of GnRH concurrently with a CIDR insert.

ment administration are described in Table 1. Although CL volume did not differ $(P=0.98)$ among treatments on d 6 , mean concentration of $\mathrm{P} 4$ was greatest $(P \leq$ 0.04 ) for $2 \mathrm{GP} 4$ cows before treatment administration, whereas mean concentrations of $\mathrm{P} 4$ did not differ $(P$ $=0.71$ ) between 1GP4 and CON cows (Table 1). As expected, mean concentrations of $\mathrm{P} 4$ from 0 to 1,200 min relative to treatment on d 6 were lowest $(P<0.01)$ for CON cows and did not differ $(P=0.82)$ between 2GP4 and 1GP4 cows (Figure 2). No interaction was detected between treatment and time $(P=0.35)$ on mean concentrations of $\mathrm{P} 4$ from 0 to $1,200 \mathrm{~min}$. Cows in the CON treatment had $(P<0.01)$ and tended $(P=$ $0.08)$ to have reduced $\mathrm{LH}$ concentration on d 6 before treatment administration compared with $1 \mathrm{GP} 4$ and 2GP4 cows, respectively $(2 \mathrm{GP} 4=0.42 \pm 0.05,1 \mathrm{GP} 4$ $=0.52 \pm 0.05$, and $\mathrm{CON}=0.29 \pm 0.06 \mathrm{ng} / \mathrm{mL})$. Peak concentrations of $\mathrm{LH}$ following $\mathrm{GnRH}$ treatment were affected by treatment $(P<0.01)$ and by the interaction between treatment and time $(P<0.01$; Figure 3$)$. Cows in the 2GP4 group had the greatest $(P<0.01)$ peak concentrations of LH from 0 to 345 min relative to treatment, but no $(P=0.80)$ differences were noted between 1GP4 and CON cows (2GP4 $=3.08 \pm 0.21$, $1 \mathrm{GP} 4=2.23 \pm 0.21$, and $\mathrm{CON}=2.14 \pm 0.25 \mathrm{ng} / \mathrm{mL})$. Dominant follicle diameter on $\mathrm{d} 6$ before treatment administration did not differ $(P=0.37)$ among treatments $(14.5 \pm 0.57 \mathrm{~mm})$. Similarly, dominant follicle

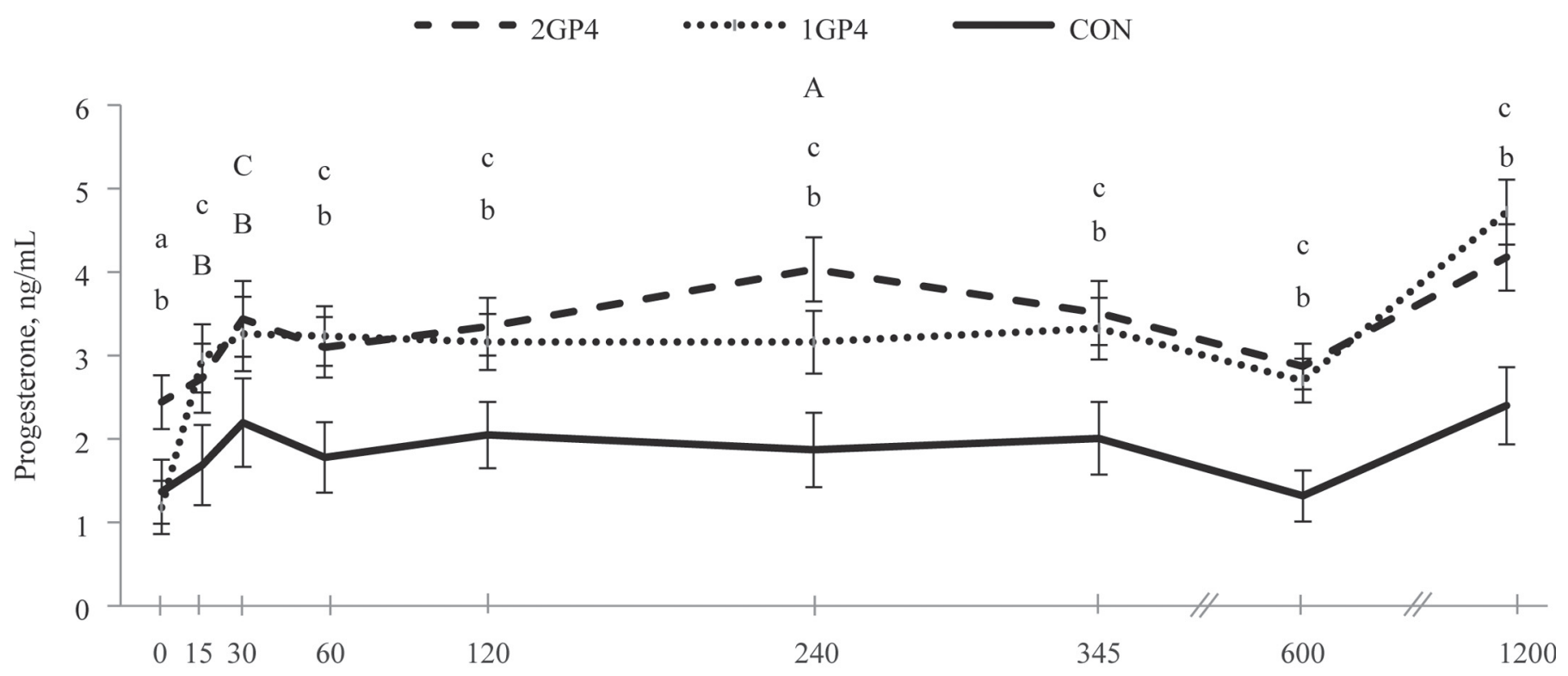

Time relative to treatment administration at estrous cycle $\mathrm{d} 6$, min

Figure 2. Concentrations of progesterone on d 6 after cows received a controlled internal drug release (CIDR) insert and a concomitant injection of $200 \mu \mathrm{g}(2 \mathrm{GP} 4)$ or $100 \mu \mathrm{g}(1 \mathrm{GP} 4)$ of GnRH, or no CIDR but treatment with $100 \mu \mathrm{g}$ of GnRH (CON). Effect of treatment, $P<0.01$ time, $P<0.01$; and treatment by time, $P=0.35$. Within a day, pairwise differences $(P<0.05)$ are represented as follows: a $=2$ GP 4 versus $1 \mathrm{GP} 4 ; \mathrm{b}=\mathrm{CON}$ versus $2 \mathrm{GP} 4 ; \mathrm{c}=\mathrm{CON}$ versus $1 \mathrm{GP} 4$. Pairwise tendencies $(P \leq 0.15)$ are represented as follows: $\mathrm{A}=2 \mathrm{GP} 4$ versus $1 \mathrm{GP} 4 ; \mathrm{B}=$ $\mathrm{CON}$ versus $2 \mathrm{GP} 4 ; \mathrm{C}=\mathrm{CON}$ versus $1 \mathrm{GP} 4$ 


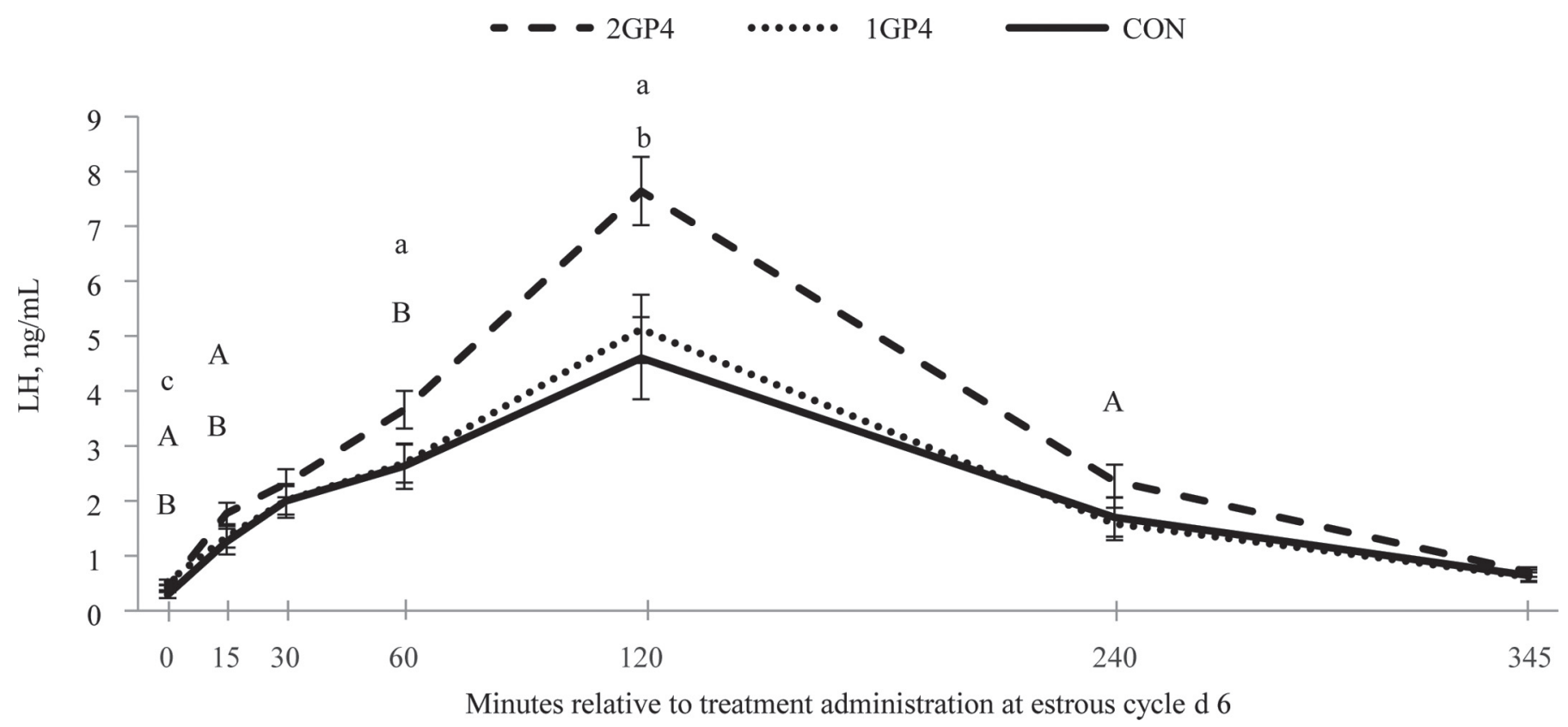

Figure 3. Concentrations of LH on d 6 after cows received a controlled internal drug release (CIDR) insert and a concomitant injection of $200 \mu \mathrm{g}(2 \mathrm{GP} 4)$ or $100 \mu \mathrm{g}(1 \mathrm{GP} 4)$ of GnRH, or no CIDR but treated with $100 \mu \mathrm{g}$ of GnRH (CON). Effect of treatment, $P<0.01 ;$ time, $P<0.01$; and treatment by time, $P<0.01$. Within a day, pairwise differences $(P<0.05)$ are represented as follows: a $=2 \mathrm{GP} 4$ versus $1 \mathrm{GP} 4$; $\mathrm{b}=\mathrm{CON}$ versus $2 \mathrm{GP} 4 ; \mathrm{c}=\mathrm{CON}$ versus $1 \mathrm{GP} 4$. Pairwise tendencies $(P \leq 0.15)$ are represented as follows: $\mathrm{A}=2 \mathrm{GP} 4$ versus $1 \mathrm{GP} 4 ; \mathrm{B}=\mathrm{CON}$ versus $2 \mathrm{GP} 4$.

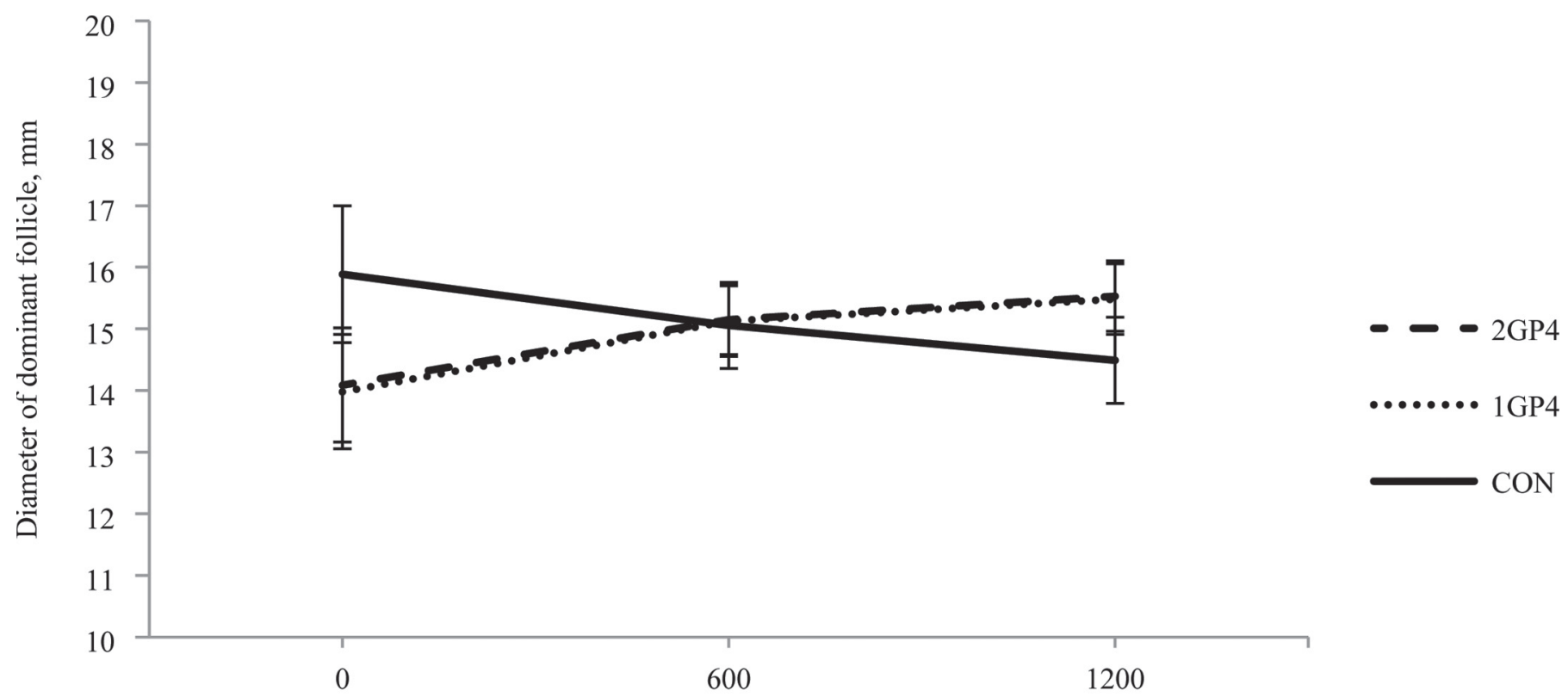

Time relative to treatment administration on $\mathrm{d} 6$, min

Figure 4. Effect of treatment and time relative to treatment on diameter of dominant follicle. There was no effect of treatment by time, $P$ $=0.48$; treatment, $P=0.75$; or time, $P=0.87$. 
diameter at 0,600 , and 1,200 min relative to treatment administration on $\mathrm{d} 6$ was not affected by treatment $(P$ $=0.75)$ or the interaction between treatment and time $(P=0.48$; Figure 4$)$.

The presynchronization protocol used in the current study was efficacious for synchronizing the estrous cycle of $68 \%$ of cows initially enrolled. Treatment with GnRH between estrous cycle d 5 and 9 is expected to result in greater ovulatory response to the GnRH injection (Vasconcelos et al., 1999) and improved embryo quality (Cerri et al., 2009). Furthermore, when the synchronization protocol is initiated during early diestrus, follicles are expected to grow under elevated concentrations of $\mathrm{P} 4$, which is expected to improve embryo quality (Rivera et al., 2011) and pregnancy per AI (Denicol et al., 2012). Therefore, in the current experiment, we aimed to determine the effect of CIDR insertion on GnRH-induced LH release at the ideal time to start the synchronization protocol: estrous cycle d 6 . Even though only cows that had luteolysis and ovulation in response to $\mathrm{PGF}_{2 \alpha}$ and $\mathrm{GnRH}$ injections, respectively, were retained in the experiment, 2GP4 cows had higher $\mathrm{P} 4$ concentration than $1 \mathrm{GP} 4$ and CON cows on d 6 before treatment administration, and CON cows tended to have lower LH concentrations than 1GP4 and 2GP4 cows. These differences in $\mathrm{P} 4$ and $\mathrm{LH}$ concentrations may be random findings as a consequence of the relatively small number of animals used in the study and the pulsatile nature of LH release. As expected, cows treated with a CIDR insert had greater concentrations of $\mathrm{P} 4$ compared with CON cows.

Cows with greater concentrations of $\mathrm{P} 4$ have reduced GnRH-induced LH release compared with cows with lower concentrations of P4 (Colazo et al., 2008; Dias et al., 2010; Giordano et al., 2012). Interestingly, the findings from the current experiment partially reject this hypothesis, because although 1GP4 cows had greater P4 concentration than CON cows, LH secretion did not differ between treatments. The difference in $\mathrm{P} 4$ concentration between the $\mathrm{CON}$ and 1GP4 treatments, however, may not have been sufficient to influence GnRH-induced LH release. It is noteworthy to mention that the current experiment used cows in early diestrus, and it is likely that cows in mid- and late-diestrus, which are expected to have higher P4 concentrations, might have a lower GnRH-induced LH release and decreased ovulatory response to treatment. Concentrations of $\mathrm{P} 4$ in CON cows were approximately $2 \mathrm{ng} / \mathrm{mL}$, typical for cows in early diestrus; therefore, one could argue that an elevation in $\mathrm{P} 4$ concentration of approximately $1 \mathrm{ng} / \mathrm{mL}$ observed in 1GP4 and 2GP4 compared with CON cows in this experiment, and in other reports (Cerri et al., 2009), may not be sufficient to affect GnRH-induced LH release. Nonetheless, Perry and Perry (2009) demonstrated that different circulating P4 concentrations influenced GnRH-induced LH release in beef heifers. Those authors reported a negative correlation between $\mathrm{P} 4$ concentration at GnRH injection and area under the LH curve (Perry and Perry, 2009); beef heifers with P4 concentration of 1 to $2 \mathrm{ng} /$ $\mathrm{mL}$ had greater GnRH-induced LH release than heifers with $\mathrm{P} 4$ concentration from 2 to 4 and $>4 \mathrm{ng} / \mathrm{mL}$. In the current study, average $\mathrm{P} 4$ concentrations from 0 to $1,200 \mathrm{~min}$ were $1.91 \pm 0.28$ and $3.31 \pm 0.24 \mathrm{ng} / \mathrm{mL}$ for CON and 1GP4 cows, respectively. Nevertheless, caution should be taken when comparing results of studies that use beef heifers and lactating dairy cows because various differences exist pertaining to clearance of $\mathrm{P} 4$ and hormone metabolism between dairy and beef animals.

In agreement with the results of studies conducted with beef and dairy cattle (Dias et al., 2010; Giordano et al., 2012), cows administered $200 \mu \mathrm{g}$ of GnRH had greater LH release than cows given $100 \mu \mathrm{g}$ of $\mathrm{GnRH}$. The current study hypothesized that the increased dose of $\mathrm{GnRH}$ would result in greater release of $\mathrm{LH}$, consequently inducing morphological follicular changes because LH stimulates steroidogenesis of the dominant follicle (Mihm et al., 2002). In addition, intrafollicular prostaglandin E synthesis (Algire et al., 1992; Filion et al., 2001) occurs in the preovulatory follicle before follicular rupture at the time of ovulation after $\mathrm{GnRH}$ injection (Peters et al., 2004). Despite the fact that the increased dose of $\mathrm{GnRH}$ increased $\mathrm{LH}$ release in the current study, dominant follicle growth did not differ among groups.

Results from the current study provide information about the acute effects, or lack thereof, of CIDR insertion concurrent with administration of GnRH on dominant follicle development. Because ovulation is expected to occur approximately $30 \mathrm{~h}$ after $\mathrm{GnRH}$ treatment (Roche et al., 1999), it is possible that additional effects of acute elevation in $\mathrm{P} 4$ on dominant follicle growth would have occurred beyond the $20 \mathrm{~h}$ from CIDR insertion investigated in the current study. Although cows in the present study were expected to have an ovulatory response due to the stage of the estrous cycle at $\mathrm{GnRH}$ injection, the study was not designed to evaluate this parameter. In the current study, alterations in intrafollicular hormones were not investigated. Because changes in follicular production of hormones are expected to occur during the final maturation of the follicle before ovulation (Filion et al., 2001; Scaramuzzi et al., 2011), the presence of elevated progesterone concurrent with GnRH injection may have a negative effect on dominant follicle hormone synthesis activity. Shaham-Albalancy 
et al. (2000) demonstrated that concentration of P4 is associated with follicular development and follicular fluid composition. Cows with a functional CL had lower concentrations of estradiol and androstenedione in the follicular fluid of dominant and co-dominant follicles compared with cows supplemented with a CIDR insert containing $1.9 \mathrm{~g}$ of $\mathrm{P} 4$ in the absence of a CL.

It is important to mention that the current study investigated the effects of CIDR treatment on GnRHinduced LH release and dominant follicle growth in cows only with a CL present. Treatment of cows without a CL with a CIDR insert concurrently with a GnRH injection would likely have a different effect on follicle development than that observed in our study. As demonstrated by Pfeifer et al. (2009), cows without a CL had increased diameter of the dominant follicle compared with cows with a CL in response to synchronization with P4 supplementation. Furthermore, it is likely that cows without a functional CL might have a different ovulatory response to the concurrent treatment of CIDR and GnRH than cows bearing a CL.

Finally, the results from the current research indicate that CIDR treatment concomitant with a $\mathrm{GnRH}$ injection did not affect GnRH-induced release of $\mathrm{LH}$ or dominant follicle growth within $20 \mathrm{~h}$ after treatment. In addition, cows treated with a CIDR insert and 200 $\mu \mathrm{g}$ of $\mathrm{GnRH}$ had an earlier rise in $\mathrm{LH}$ and greater $\mathrm{LH}$ peak concentration than cows treated with $100 \mu \mathrm{g}$ of GnRH. However, the increased GnRH dose did not have an acute effect on dominant follicle growth. Further research should be conducted to investigate the prolonged effects of a CIDR insert on dominant follicle development.

\section{ACKNOWLEDGMENTS}

The authors thank James Linn (University of Minnesota, St. Paul) and the University of Minnesota-St. Paul dairy barn staff. This article is contribution number 15-181-J from the Kansas Agricultural Experiment Station (Manhattan).

\section{REFERENCES}

Algire, J. E., A. Srikandakumar, L. A. Guilbault, and B. R. Downey. 1992. Preovulatory changes in follicular prostaglandins and their role in ovulation in cattle. Can. J. Vet. Res. 56:67-69.

Cerri, R. L. A., H. M. Rutigliano, R. G. S. Bruno, and J. E. P. Santos. 2009. Progesterone concentration, follicular development and induction of cyclicity in dairy cows receiving intravaginal progesterone inserts. Anim. Reprod. Sci. 110:56-70.

Chebel, R. C., M. J. Al-Hassan, P. M. Fricke, J. E. P. Santos, J. R. Lima, C. A. Martel, J. S. Stevenson, R. Garcia, and R. L. Ax. 2010. Supplementation of progesterone via controlled internal drug release inserts during ovulation synchronization protocols in lactating dairy cows. J. Dairy Sci. 93:922-931.
Chebel, R. C., J. E. P. Santos, R. L. A. Cerri, H. M. Rutigliano, and R. G. S. Bruno. 2006. Reproduction on dairy cows following progesterone insert presynchronization and resynchronization protocols. J. Dairy Sci. 89:4205-4219.

Chebel, R. C., A. A. Scanavez, P. R. B. Silva, J. G. N. Moraes, L. G. D. Mendonça, and G. Lopes Jr. 2013. Evaluation of presynchronized resynchronization protocols for lactating dairy cows. J. Dairy Sci. 96:1009-1020.

Colazo, M. G., J. P. Kastelic, H. Davis, M. D. Rutledge, M. F. Martinez, J. A. Small, and R. J. Mapletoft. 2008. Effects of plasma progesterone concentrations on LH release and ovulation in beef cattle given GnRH. Domest. Anim. Endocrinol. 34:109-117.

Denicol, A. C., G. Lopes Jr., L. G. Mendonça, F. A. Rivera, F. Guagnini, R. V. Perez, J. R. Lima, R. G. Bruno, J. E. Santos, and R. C. Chebel. 2012. Low progesterone concentration during the development of the first follicular wave reduces pregnancy per insemination of lactating dairy cows. J. Dairy Sci. 95:1794-1806.

Dias, F. C., M. G. Colazo, J. P. Kastelic, R. J. Mapletoft, G. P. Adams, and J. Singh. 2010. Progesterone concentration, estradiol pretreatment, and dose of gonadotropin-releasing hormone affect gonadotropin-releasing hormone-mediated luteinizing hormone release in beef heifers. Domest. Anim. Endocrinol. 39:155-162.

Ferguson, J. D., D. T. Galligan, and N. Thomsen. 1994. Principal descriptors of body condition score in HO cows. J. Dairy Sci. 77:2695-2703.

Filion, F., N. Bouchard, A. K. Goff, J. G. Lussier, and J. Sirois. 2001. Molecular cloning and induction of bovine prostaglandin E synthase by gonadotropins in ovarian follicles prior to ovulation in vivo. J. Biol. Chem. 276:34323-34330.

Galvão, K. N., J. E. Santos, S. O. Juchem, R. L. Cerri, A. C. Coscioni, and M. Villasenor. 2004. Effect of addition of a progesterone intravaginal insert to a timed insemination protocol using estradiol cypionate on ovulation rate, pregnancy rate and late embryonic loss in lactating dairy cows. J. Anim. Sci. 82:3508-3517.

Giordano, J. O., P. M. Fricke, J. N. Guenther, G. Lopes Jr., M. M. Herlihy, A. B. Nascimento, and M. C. Wiltbank. 2012. Effect of progesterone on magnitude of the luteinizing hormone surge induced by two different doses of gonadotropin-releasing hormone in lactating dairy cows. J. Dairy Sci. 95:3781-3793.

Kenyon, A. G., G. Jr. Lopes, L. G. D. Mendonça, J. R. Lima, R. G. Bruno, A. C. Denicol, and R. C. Chebel. 2012. Ovarian responses and embryo survival in recipient lactating Holstein cows treated with equine chorionic gonadotropin. Theriogenology 77:400-411.

Kirkpatrick, B. L., E. Esquivel, P. C. Gentry, G. E. Moss, M. E. Wise, and D. L. Hamernik. 1998. Regulation of amounts of mRNA for $\mathrm{GnRH}$ receptors by estradiol and progesterone in sheep. Endocrine 8:93-99.

Lima, J. R., F. A. Rivera, C. D. Narciso, R. Oliveira, R. C. Chebel, and J. E. Santos. 2009. Effect of increasing amounts of supplemental progesterone in a timed artificial insemination protocol on fertility of lactating dairy cows. J. Dairy Sci. 92:5436-5446.

Mihm, M., M. A. Crowe, P. G. Knight, and E. J. Austin. 2002. Follicle Wave Growth in Cattle. Reprod. Domest. Anim. 37:191-200.

NAHMS. 2007. Part IV: Reference of dairy cattle health and management practices in the United States. USDA, Animal and Plant Health Inspection Service, Veterinary Services, Center for Epidemiology and Animal Health, National Animal Health Monitoring System. Fort Collins, CO.

Perry, G. A., and B. L. Perry. 2009. Effect of the timing of controlled internal drug-releasing device insertion on the gonadotropin-releasing hormone-induced luteinizing hormone surge and ovulatory response. J. Anim. Sci. 87:3983-3990.

Peters, M. W., J. R. Pursley, and G. W. Smith. 2004. Inhibition of intrafollicular PGE2 synthesis and ovulation following ultrasoundmediated intrafollicular injection of the selective cyclooxygenase-2 inhibitor NS-398 in cattle. J. Anim. Sci. 82:1656-1662.

Pfeifer, L. F., R. J. Mapletoft, J. P. Kastelic, J. A. Small, G. P. Adams, N. J. Dionello, and J. Singh. 2009. Effects of low versus physiologic plasma progesterone concentrations on ovarian follicular development and fertility in beef cattle. Theriogenology 72:1237-1250. 
Rispoli, L. A., and T. M. Nett. 2005. Pituitary gonadotropin-releasing hormone $(\mathrm{GnRH})$ receptor: Structure, distribution and regulation of expression. Anim. Reprod. Sci. 88:57-74.

Rivera, F. A., L. G. D. Mendonça, G. Lopes Jr., J. E. Santos, R. V. Perez, M. Amstalden, A. Correa-Calderón, and R. C. Chebel. 2011. Reduced progesterone concentration during growth of the first follicular wave affects embryo quality but has no effect on embryo survival post transfer in lactating dairy cows. Reproduction 141:333-342.

Roche, J. F., E. J. Austin, M. Ryan, M. O'Rourke, M. Mihm, and M. G. Diskin. 1999. Regulation of follicle waves to maximize fertility in cattle. J. Reprod. Fertil. Suppl. 54:61-71.

Scaramuzzi, R. J., D. T. Baird, B. K. Campbell, M. A. Driancourt, J. Dupont, J. E. Fortune, R. B. Gilchrist, G. B. Martin, K. P. McNatty, A. S. McNeilly, P. Monget, D. Monniaux, C. Viñoles, and R. Webb. 2011. Regulation of folliculogenesis and the determination of ovulation rate in ruminants. Reprod. Fertil. Dev. 23:444-467.
Shaham-Albalancy, A., M. Rosenberg, Y. Folman, Y. Graber, R. Meidan, and D. Wolfenson. 2000. Two methods of inducing low plasma progesterone concentrations have different effects on dominant follicles in cows. J. Dairy Sci. 83:2771-2778

Stevenson, J. S., D. E. Tenhouse, R. L. Krisher, G. C. Lamb, J. E. Larson, C. R. Dahlen, J. R. Pursley, N. M. Bello, P. M. Fricke, M. C. Wiltbank, D. J. Brusveen, M. Burkhart, R. S. Youngquist, and H. A. Garverick. 2008. Detection of anovulation by heatmount detectors and transrectal ultrasonography before treatment with progesterone in a timed insemination protocol. J. Dairy Sci. 91:2901-2915.

Vasconcelos, J. L. M., R. W. Silcox, G. J. M. Rosa, J. R. Pursley, and M. C. Wiltbank. 1999. Synchronization rate, size of the ovulatory follicle, and pregnancy rate after synchronization of ovulation beginning on different days of the estrous cycle in lactating dairy cows. Theriogenology 52:1067-1078. 